\title{
BMJ Open Challenges of enforcing cellphone use while driving laws among police in the USA: a cross-sectional analysis
}

\author{
Toni Marie Rudisill (D) , ${ }^{1}$ Motao $\mathrm{Zhu}^{2}$
}

To cite: Rudisill TM, Zhu M. Challenges of enforcing cellphone use while driving laws among police in the USA: a crosssectional analysis. BMJ Open 2021;11:e049053. doi:10.1136/ bmjopen-2021-049053

- Prepublication history and supplemental material for this paper is available online. To view these files, please visit the journal online (http://dx.doi. org/10.1136/bmjopen-2021049053).

Received 14 January 2021 Accepted 08 June 2021

Check for updates

(C) Author(s) (or their employer(s)) 2021. Re-use permitted under CC BY-NC. No commercial re-use. See rights and permissions. Published by BMJ.

${ }^{1}$ Epidemiology, West Virginia University, Morgantown, West Virginia, USA

${ }^{2}$ Center for Injury Research and Policy, Nationwide Children's Hospital, Columbus, Ohio, USA

Correspondence to Dr Toni Marie Rudisill; trudisill@hsc.wvu.edu

\section{ABSTRACT}

Objectives Research suggests that cellphone use while driving laws may be difficult for police to enforce in the USA, but this is unknown. A national survey of police officers was conducted to determine whether barriers to enforcing these laws exist, what aspects of laws make them easier to enforce and ways to discourage the behaviour among drivers.

Design Cross-sectional survey.

Setting USA.

Participants Individuals $>18$ years of age employed as a law enforcement officer from all 50 states were recruited via convenience sampling through multiple modalities from November 2019 to April 2020. Officers ( $N=353)$ from 31 states participated.

Primary and secondary outcome measures Descriptive statistics and multi-level logistic regression analyses were run to assess the responses.

Results The most common barriers to enforcing texting bans (ie, the most prevalent law) were drivers concealing their phone use $(78 \%)$ and the officer not being able to determine what the driver was doing on their phone $(65 \%)$. If a universal hand-held cellphone ban was in effect in their state, officers were $77 \%$ less likely (adjusted $\mathrm{OR}=0.23 ; 95 \% \mathrm{Cl} 0.08$ to 0.70 ) to report that a texting ban was difficult to adjudicate. The majority of officers $(86 \%)$ agreed that having one general law that prohibits any type of hand-held cellphone use would aid with enforcement, and that laws must be a primary offence (87\%), and be applicable to all licensed drivers (91\%). Most officers felt that driver education is needed.

Conclusions While numerous barriers to enforcement were identified, opportunities exist to improve current legislation to aid enforcement efforts and to prevent the behaviour among drivers.

\section{INTRODUCTION}

Over the past 20 years, a multitude of cellphone use while driving (CPWD) laws have been enacted throughout the USA to protect road users. The most common law passed among states is a universal texting ban (UTB), which prohibits any licensed driver from sending or reading text-based messages on a hand-held device; 48 states have a UTB. ${ }^{1}$ The second most common law enacted is a young driver cellphone ban (YDB). This law typically applies to drivers who are under a

\section{Strengths and limitations of this study}

No national studies have surveyed officers to determine if barriers to cellphone law enforcement exist.

- Officers from 31 states participated in the survey.

- The response rate was low especially from officers from the northeastern USA.

- Officers who chose to participate may be fundamentally different from those who did not.

- As this was a survey, socially acceptable responses may have been provided.

particular age (ie, under 18, 19 or 21 years of age) or licensure status (ie, individuals who hold a learner's permit or intermediate driver's license) and prohibits them from any hand-held cellphone use except in emergency situations; currently, 38 states have a YDB. ${ }^{1}$ The third most common law passed is a universal hand-held cellphone ban (UHB). This law generally forbids any licensed driver from holding a cellphone in their hand; 22 states have a UHB. ${ }^{1}$ While these are the most common types of laws passed, there are some variations between states. ${ }^{1}$

While the enactment of such laws is important for public safety, legislation is only effective if it is enforced by police. Research indicates that active enforcement can deter drivers from engaging in adverse behaviours. ${ }^{2}{ }^{3}$ Very few studies have investigated the enforcement of CPWD laws; among such studies, most have determined that CPWD violations make up only $1 \%-8 \%$ of all traffic citations written. ${ }^{4-7}$ Because the frequency of citation issuance for these violations appears low, it is believed that these laws may be difficult for police to enforce. Previous research has shown that laws with fewer perceived barriers are enforced more frequently by police. ${ }^{8}$ However, to the authors' knowledge, only two studies have actually consulted police on the potential barriers to enforcing CPWD laws in the USA. ${ }^{9} 10$ These qualitative studies were conducted separately 
with police in West Virginia and Washington states, which have all three CPWD laws in effect. ${ }^{1910}$ Despite the states' geographical distance from one another, both studies found that numerous but similar barriers to CPWD enforcement were experienced by officers. Officers from both states claimed that it is often difficult to discern what drivers are actually doing on their phones (ie, calling, texting, using the internet) and proving their observation in court should the citation be contested. Officers noted that using a cellphone while driving is socially accepted by the public, and many drivers engage in these behaviours. Additionally, individuals tend to overestimate their driving ability and believe they can safely drive while using a cellphone. Officers claimed that the manner in which laws are written is also problematic. Laws can be written very specifically, which can be difficult for officers because they have to identify a particular behaviour that a driver is performing often from a distance. Laws can also be written in such a manner where certain behaviours are permitted, while other behaviours are not. ${ }^{9}{ }^{10}$ An example would be if the law prohibits drivers from texting but allows them to operate a global positioning system (GPS), which is often a cellphone application. It would be nearly impossible for the officer to identify whether the driver is texting or using GPS. Thus, if the officer pulls the driver over, the driver could claim they were using GPS to avoid a citation. Many state-laws have these 'legal exceptions/ loop-holes'.

Because states can have different combinations of CPWD laws in effect, it is entirely unknown whether officers in other states experience challenges similar to those noted in the Washington and West Virginia studies. Thus, the purpose of this study was to conduct a national survey of police officers to determine whether similar barriers to enforcing CPWD laws exist, what aspects of CPWD laws make them easier for police to enforce and potential ways to reduce CPWD from an officers' perspective. If common barriers are identified among states-especially those with comparable laws, current CPWD legislation could be amended to make enforcement easier for police.

\section{METHODS}

\section{Study population}

The study population included any individual employed as a law enforcement officer in the USA who was $\geq 18$ years of age at time of survey.

\section{Survey development, validity and reliability}

The survey, which was found valid and reliable, has been described in detail elsewhere. ${ }^{11}$ Briefly, the survey contained 33 questions in total including skip logic and was constructed using Qualtrics software. The survey asked questions pertaining to how often the officer issued citations for CPWD infractions, factors which influenced their decision to apprehend a driver, how easy or difficult the adjudication process was in their jurisdiction for CPWD offences, potential challenges encountered when enforcing the CPWD laws in effect in their patrol area, aspects of CPWD laws that do or could aid in their enforcement, ways to prevent CPWD among drivers, in addition to demographics. Most questions were comprised of a series of statements in which the respondent could agree or disagree with. The responses mainly consisted of a 5-point Likert scale ranging from, 'Strongly disagree (1)' to 'Strongly agree (5)'. The survey was designed to be completed in $<20 \mathrm{~min}$. To encourage participation, the survey was anonymised (ie, the officers' names, department affiliations, or any personally identifying information were not collected).

\section{Survey sampling and distribution}

Officers were recruited via convenience sampling. The survey was released mid-November 2019 through April 2020. In order to distribute the survey, police agencies were randomly selected throughout the USA and all 50 states were engaged. The agencies were contacted via their social media pages, websites, email addresses or listed phone numbers. The agencies were briefly informed about the survey, its purpose and provided an electronic link to participate. Respondents were encouraged to share the electronic link with anyone that met the inclusion criteria. In addition to randomly contacting individual departments, the survey was posted to policeaffiliated social media pages and organisations. The National Fraternal Order of Police also provided their state lodges a link to the survey, who in turn, passed the information on to individual officers who were members of the organisation. The survey was also distributed among members of the International Association of Campus Law Enforcement. To encourage participation, respondents who completed the survey could enter into a drawing to receive a $\$ 100$ gift card.

\section{Statistical analyses}

All data management and analyses were conducted using SAS V.9.4. Descriptive statistics were calculated for responses. Because UTBs were in effect in 48 states $(96 \%)$, additional analyses were conducted to determine if any demographic factors (ie, age, sex, race, education level or years of experience in law enforcement) or other CPWD laws (ie, YDB or UHB) were independently associated with an officer responding that a UTB law was difficult to adjudicate. Officers' responses, which were on a 5-point Likert scale, were collapsed and made binary (ie, the responses for, 'Very difficult to adjudicate', and 'Difficult to adjudicate', were combined and compared with the other possible responses). Because the dependent variable was binary and officers could be from the same states (ie, they could be correlated), a multilevel logistic regression model with an exchangeable correlation matrix was used. ${ }^{12}$ Additional analyses were undertaken to determine if any of these demographic factors or other laws were potential confounders of one another in their relationship with the dependent variable. This was accomplished by first running the crude models and 
seeing if any of the variables were statistically associated with an officer reporting that a UTB was difficult to adjudicate. The other demographic factors were each separately added to the model and the crude and adjusted models were compared. If there was a $10 \%$ change in the OR between the crude and adjusted model, confounding was suspected. Hypothesis tests were two-sided with the a priori level of significance set at $\alpha=0.05$.

\section{Patient and public involvement}

It was not possible to involve patients or the public in the design, or conduct, or reporting, or dissemination plans of our research.

\section{RESULTS}

Officers ( $\mathrm{N}=353$ ) from 31 states participated in the national survey. A map indicating which states officers were from is shown in the online supplemental appendix 1 . The majority of officers were $35-54$ years of age (65\%), men $(88 \%)$, of white race $(89 \%)$ and from the southern USA (67\%) (table 1). Most were from states with UTB $(94 \%)$ or YDB $(86 \%)$ in effect. Only $21 \%$ of respondents came from states with UHB.

Numerous barriers to enforcing UTB were reported by officers (table 2). Nearly $78 \%$ of respondents agreed that drivers often try to conceal their texting behaviours. A majority of officers (ie, $>60 \%$ ) also agreed that their laws have exceptions which permit drivers to perform some behaviours but not others and that they cannot often tell what the driver is actually doing on their phone. Nearly half of the officers agreed that drivers do not seem supportive of the law (49\%) and do not fully understand what the law permits $(57 \%)$.

The results from the multilevel logistic regression analyses showed that most demographic factors (ie, officers' age, race, years of experience or education) were not associated with officers perceived difficulty of adjudicating UTBs, while UHB were associated (table 3). Through the confounding analyses, YDB was identified as the only confounder of the relationship between the presence of a UHB and an officer reporting that UTB was difficult to adjudicate. After adjusting for YDB, if a UHB was in effect in their state, officers were $77 \%$ less likely (OR $0.23 ; 95 \%$ CI 0.08 to 0.70 ) to report that a UTB was difficult to adjudicate.

There were numerous aspects of CPWD laws that do or could make them easier for police to enforce. Among respondents, $91 \%$ agreed that laws must be applicable to all licensed drivers (table 4). The majority of officers also agreed that laws must be made a primary offence $(87 \%)$. In the USA, traffic offences can be designated as primary or secondary. A primary offence means an officer can pull a driver over if they observe that specific behaviour. Secondary offences are violations in which an officer cannot pull a driver over for solely. A driver can only be cited for a secondary offence if they were originally pulled over for committing a primary offence. Additionally, $86 \%$ of respondents agreed that having one general law that prohibits hand-held cellphone use of any kind would help with enforcement.

Officers were also asked what prevention measures could substantially reduce cellphone use among drivers (table 5). Nearly $88 \%$ agreed that educating the public on what current traffic laws do or do not permit would be beneficial. Nearly $85 \%$ of respondents also agreed that educating the public on the dangers of CPWD or changing the culture to make CPWD less socially accepted would also help reduce the behaviour. A large majority of officers also agreed that educating the public on how to use hands-free technology (78\%) could help.

\section{DISCUSSION}

This study is the first to investigate the potential barriers to enforcing CPWD among police officers across the USA. The findings revealed that there are numerous challenges that officers face when enforcing CPWD laws, especially UTB which are the most common law in effect. The study also found that ample opportunities exist to amend legislation or improve public health efforts from an officers' perspective. One of the biggest challenges for officers noted in this study and others is determining what the driver is actually doing on their cellphone. ${ }^{9} 10$ Given the vast technological capabilities of cellphones, the driver could easily be engaging in a myriad of behaviours (ie, dialling a phone number, terminating a call, sending/reading texts, browsing the internet). If the driver is concealing their behaviour, which was another common barrier, then officers may not be able to determine what the driver is doing. The uncertainty of the drivers' activity coupled with how most of the CPWD laws are written complicate enforcement efforts. A majority of officers agreed that some CPWD laws are written too specific, or they are written in such a manner where some behaviours are permitted, while others are not. These barriers to enforcement were also noted in previous studies conducted with officers in Washington and West Virginia. ${ }^{9}{ }^{10}$ For example, if the law specifically states that a driver cannot send or read text-based messages, it may not necessarily cover other activities such as watching a video, making a cellphone call and so on. Also, if a law states that a driver cannot conduct a hand-held phone conversation, but is allowed to end a call or use GPS, these essentially create 'legal loopholes' for drivers. These situations not only complicate enforcement for officers, but can confuse drivers' understanding of what the law does and does not permit.

From a policy perspective, several opportunities exist to amend or implement CPWD laws to make them easier for police to enforce. First, this study found that UHB may help with enforcement of UTB. This situation is likely due to the fact that UHBs state that drivers cannot hold a phone in their hand. Thus, if a driver is texting on a hand-held device, it may be easier to cite them for a UHB infraction as opposed to texting. This has been 
Open access

Table 1 Demographic characteristics of police officers who participated in national survey $(\mathrm{N}=353)^{\star}$

\section{Characteristics}

\section{$\mathbf{N}$}

$\%$

Age (in years)

$\begin{array}{lr}18-34 & 47 \\ 35-44 & 68 \\ 45-54 & 120 \\ >55 & 55\end{array}$

Missing

63

Sex

Male 254

$47 \quad 16.2$

$68 \quad 23.5$

$120 \quad 41.4$

Female $\quad 35$

Missing $\quad 64$

Race

White 255

$255 \quad 88.5$

Other 33

Missing 65

Education

High school or equivalency $\quad 55$

Associate degree 66

Bachelor's degree 115

22.8

Graduate degree 53

Missing 64

Law enforcement experience (years)

\begin{tabular}{lrc}
$<15$ & 101 & 34.7 \\
$15-24$ & 84 & 28.9 \\
$\geq 25$ & 106 & 36.4 \\
Missing & 62 & \\
\hline
\end{tabular}

Census region $\dagger$

$\begin{array}{lrr}\text { Northeast } & 8 & 2.8 \\ \text { Midwest } & 42 & 14.7 \\ \text { South } & 192 & 67.4 \\ \text { West } & 43 & 15.1 \\ \text { Missing } & 68 & \end{array}$

State-level universal texting ban in effect†

$\begin{array}{lrr}\text { Yes } & 267 & 93.7 \\ \text { No } & 18 & 6.3 \\ \text { Missing } & 68 & \end{array}$

State-level universal hand-held cellphone ban in effect†

\begin{tabular}{lrc}
\hline Yes & 59 & 20.7 \\
\hline No & 226 & 79.3 \\
\hline Missing & 68 & \\
State-level young driver all cellphone bans in effect† & & 85.6 \\
Yes & 244 & 14.4 \\
\hline No & 41 & \\
\hline Missing & 68 & \\
\hline
\end{tabular}

*Percentages may not add to $100 \%$ due to rounding.

†'Missing' means the officer did not indicate their state of employment. 
Table 2 Barriers experienced by officers when enforcing texting while driving laws $(\mathrm{N}=258)^{\star}$

\section{Barrier}

Per cent experiencing this barrier

Drivers try to conceal texting 78.3

Current law has exceptions which allow drivers to perform certain behaviours but $\quad 66.2$ not others (eg, drivers are not permitted to text, but they may use global positioning system, or manually dial a phone number)

\begin{tabular}{ll} 
Officer cannot prove what the driver is actually doing on their phone (ie, texting vs & 64.5 \\
watching a video, surfing the internet, dialling a number) & 57.3 \\
Drivers do not fully understand what the law permits & 49.2 \\
\hline Drivers are not supportive of this law & 40.5 \\
Surrounding states have different laws which confuse interstate drivers & 35.9 \\
Current law is too narrowly focused & 24.4 \\
Law is outdated because technology advanced faster & 23.5 \\
Current law is unclear & 23.3 \\
Judges or courts are not supportive of law & 16 \\
\hline Officer does not fully understand what the law permits & 13.7 \\
Officer wants to maintain a positive relationship with the public & 12 \\
Fellow officers are not supportive of law & 4.3 \\
\hline Department management is not supportive of law &
\end{tabular}

*This question asked if the officer experienced any of the perceived barriers listed above when enforcing texting while driving laws. Responses consisted of, 'yes', 'no' or 'unsure'. The percentage shown is those who indicated that they experienced this barrier when enforcing this law if it was in effect in their jurisdiction. The response rate for this question was $73 \%$.

seen in previous study where UHB violations were written much more frequently than UTB or YDB violations in multiple states. ${ }^{4}$ While most states have a UTB, less than half have a UHB. ${ }^{1}$ States or municipalities with UTB may want to consider implementing UHB to aid enforcement efforts. Second, these findings suggest that YDB may have limited utility in the presence of other CPWD laws. The majority of officers agreed that removing age or licensure requirements from CPWD laws could make them easier to enforce. Additionally, this study also found that states seeking to amend their laws may want to consider neighbouring states' legislation. Differences in state laws was also a barrier to enforcement as it can confuse interstate drivers. While most states have a UTB, fewer states have UHB or YDB. Lastly, while existing laws could be clarified, states may consider implementing a law that permits no hand-held cellphone use of any kind for drivers as nearly $86 \%$ of officers stated that this would be beneficial to enforcement.

In addition to potential policy changes, the study has public health implications. From an officer's perspective, there may be several viable options to reduce this dangerous and prevalent behaviour among drivers. ${ }^{13}$ The majority of officers agreed that drivers need more education on the CPWD laws and how to use hands-free technology. Many also agreed that increasing penalties, changing the culture surrounding CPWD, and technological solutions may also reduce CPWD.

However, it is not entirely clear if these prevention measures suggested by police would actually be effective in reducing CPWD as the intervention literature is severely lacking. Very few studies have investigated whether educational interventions reduce CPWD behaviours; the results of extant studies are mixed. ${ }^{14-18}$ The relationship between increased penalties and behavioural changes among drivers has been investigated with other traffic safety infractions such as red light running, speeding, laxed seat belt use and impaired driving recidivism in the USA and abroad; the findings of these studies are also varied. ${ }^{19-25}$ As for cultural norms, research has shown that distracted driving campaigns are less effective than anti-drunk driving campaigns, particularly among younger drivers. ${ }^{26}$ Cultural norms are known to influence individuals' behaviour. $^{27}{ }^{28}$ Changing the culture surrounding CPWD is likely needed but will require a substantial, sustained effort in order it to be effective.

As for technology, various cellphone applications already exist and are freely or commercially available for drivers to use to disable certain cellphone functions while a vehicle is in motion; however, rigorous evaluations of this technology have not been conducted. ${ }^{29}{ }^{30}$ One concern with this technology is acceptability as drivers may be reluctant to use it if the functions of their phones are altered. Few studies have investigated the acceptability of this technology. ${ }^{31-33}$ A study conducted among teen drivers in the USA found that participants were unwilling to use this technology if it impeded the navigation or music functionality on their phones; the study also determined that those who frequently engaged in texting while driving were less accepting of the technology. ${ }^{31}$ An Australian study of drivers ( $N=712$ ) 18-90 years of age determined that women were more likely to use this technology and that most drivers did not want 
Table 3 Characteristics of officers that were associated with reporting that a universal texting ban was difficult to adjudicate

\begin{tabular}{|c|c|c|c|c|}
\hline \multirow[b]{2}{*}{ Characteristic } & \multicolumn{2}{|c|}{ Crude model } & \multicolumn{2}{|c|}{ Adjusted model } \\
\hline & OR & $95 \% \mathrm{Cl}$ & OR & $95 \% \mathrm{Cl}$ \\
\hline \multicolumn{5}{|l|}{ Age (in years) } \\
\hline $18-34$ & 1.20 & 0.73 to 1.98 & - & - \\
\hline $35-44$ & 1.08 & 0.62 to 1.89 & - & - \\
\hline $45-54$ & 1.25 & 0.78 to 2.02 & - & - \\
\hline$>55$ & 1 & Referent & - & - \\
\hline \multicolumn{5}{|l|}{ Sex } \\
\hline Male & 1.43 & 0.62 to 3.32 & - & - \\
\hline Female & 1 & Referent & - & - \\
\hline \multicolumn{5}{|l|}{ Race } \\
\hline White & 1.37 & 0.69 to 2.70 & - & - \\
\hline Other & 1 & Referent & - & - \\
\hline \multicolumn{5}{|l|}{ Education } \\
\hline High school or equivalency & 0.69 & 0.40 to 1.19 & - & - \\
\hline Associate degree & 1 & 0.58 to 1.74 & - & - \\
\hline Bachelor's degree & 1.01 & 0.55 to 1.84 & - & - \\
\hline Graduate degree & 1 & Referent & - & - \\
\hline \multicolumn{5}{|c|}{ Law enforcement experience (in years) } \\
\hline$<15$ & 1.03 & 0.55 to 1.93 & - & - \\
\hline $15-24$ & 1.24 & 0.62 to 2.48 & - & - \\
\hline$\geq 25$ & 1 & Referent & - & - \\
\hline \multicolumn{5}{|c|}{ State-level universal hand-held cellphone ban in effect } \\
\hline Yes & 0.32 & 0.12 to 0.84 & 0.23 & 0.08 to 0.70 \\
\hline No & 1 & Referent & 1 & Referent \\
\hline \multicolumn{5}{|c|}{ State-level young driver all cellphone bans in effect } \\
\hline Yes & 1.10 & 0.27 to 4.58 & 2.73 & 0.59 to 12.69 \\
\hline No & 1 & Referent & 1 & Referent \\
\hline
\end{tabular}

*A multilevel logistic regression model which accounted for the correlation of state was used to estimate ORs. The dependent variable was whether or not an officer perceived that universal texting bans were difficult to adjudicate. Separate crude models were run between each characteristic noted and the outcome. Multivariable models were adjusted for confounders of the relationship between statistically significant independent variables (ie, the presence of a universal hand-held ban) and the outcome.

their calls blocked along with their music, GPS or Bluetooth capabilities. ${ }^{32}$ In actual field tests, a study conducted among a small group of US employees $(\mathrm{N}=44)$ found that most disliked the technology after using it for several weeks even though it appeared to reduce their calls. ${ }^{33}$ Two studies which investigated the efficacy of this technology among younger drivers found that they will over-ride the technology to use a cellphone while driving. ${ }^{34}{ }^{35}$ One of these studies did report that calls and texts were decreased when this technology was enabled. ${ }^{35}$ Another technological solution that could potentially aid law enforcement is automated traffic enforcement. Automated traffic enforcement is when cameras or monitors are installed at intersections and citations are automatically issued to drivers (via license plate tracking) who appear to violate laws. It is currently used in limited locations in the USA mainly for red light running and/or speeding. ${ }^{36}$ Even though automated traffic enforcement can deter risky driver behaviour and the American public is mildly in favour of it for enforcing certain traffic violations, it is highly politicised and illegal in several states. ${ }^{36-46}$ As this was not specifically asked in the survey, it is not clear if this technology would help with cellphone law enforcement as a picture may not reveal what the driver is doing on their cellphone at the time of the infraction. Thus, more research and rigorous evaluations of interventions are clearly needed.

While the findings of this study are important to the extant traffic safety literature, they are not without limitation. Even though the survey was distributed throughout all 50 states, the response rate was low and could not realistically be determined. Research shows that surveys involving police typically have low response rates. ${ }^{47}$ This is attributed to the multifaceted nature of their job where they have competing demands, emergency calls to 
Table 4 Aspects of cellphone use while driving laws which does or could make them easier for police to enforce $(\mathrm{N}=304)^{*}$

\begin{tabular}{llll}
\hline Aspect & $\begin{array}{l}\text { Per cent who strongly } \\
\text { agreed or agreed }\end{array}$ & $\begin{array}{l}\text { Mean } \\
\text { response }\end{array}$ & SD \\
\hline Making these laws applicable to all licensed drivers & 90.7 & 4.5 & 0.8 \\
\hline Making these laws a primary offence & 86.5 & 4.4 & 0.9 \\
\hline Having one general law that prohibits hand-held cellphone use of any kind & 85.8 & 4.3 & 0.9 \\
$\begin{array}{l}\text { Eliminating age or license requirements (ie, the law does not just apply to drivers } \\
\text { under a certain age or licensure types). }\end{array}$ & 4.2 & 1 \\
$\begin{array}{l}\text { Eliminating legal exceptions, which permit some behaviours but not others } \\
\text { Writing these laws more broadly and including all distracting behaviours (eg, } \\
\text { personal grooming, eating, pets sitting in the driver's lap) }\end{array}$ & 72.3 & 4 & 1.1 \\
\hline
\end{tabular}

*This question asked which aspects of cellphone laws do or could make them easier to enforce and the officers were presented with these options. Responses were on a 5-point Likert scale ranging from 'Strongly disagree (1)' to 'Strongly agree (5)'. The mean value along with the percentage of respondents who 'Strongly agreed' or 'Agreed' with the statement were combined and shown. The response rate for this question was $86 \%$.

respond to, active patrols to make, court appearances to attend and so on. Second, the response rate from northeastern states, which often have UHB in effect, was also much lower than the other regions. The lower response rate in this area was partially attributed to the COVID-19 pandemic. Also, officers for this survey were recruited by convenience sampling. While many departments were given an electronic link to the survey and were encouraged to distribute it to anyone who met the inclusion criteria, there was no guarantee that it was circulated. Additionally, the survey was designed to be anonymous so officers would not fear potential repercussion from giving their opinions; this was done to increase participation rates. Thus, it was unknown whether officers who responded were from different departments. Because officers from the same department could be correlated and department affiliation was not collected to protect anonymity, regression models were adjusted for state correlation instead. It is also possible that those who participated may be fundamentally different from those who did not participate. This could lead to a selection bias. Lastly, as this was a survey, it is entirely plausible that reporting or recall biases existed. Officers could have chosen to give more socially appropriate responses or may have not accurately recalled certain behaviours or situations.

\section{CONCLUSION}

CPWD is a dangerous and prevalent behaviour among drivers in the USA. ${ }^{13}$ In order to mitigate the risk, drivers

Table 5 Officers' opinions regarding prevention measures which could substantially reduce cellphone use among drivers $(\mathrm{N}=290)^{*}$

\begin{tabular}{|c|c|c|c|}
\hline Prevention measure & $\begin{array}{l}\text { Per cent who strongly agreed } \\
\text { or agreed }\end{array}$ & $\begin{array}{l}\text { Mean } \\
\text { response }\end{array}$ & SD \\
\hline Educating the public on what the current traffic laws do or do not permit & 87.6 & 4.3 & 0.8 \\
\hline Educating the public on the dangers of cellphone use while driving & 84.8 & 4.2 & 1 \\
\hline $\begin{array}{l}\text { Changing the current culture to make cellphone use while driving more } \\
\text { socially unacceptable }\end{array}$ & 84.1 & 4.2 & 0.9 \\
\hline $\begin{array}{l}\text { Educating the public on how to use hands-free technology (eg, Bluetooth, } \\
\text { external hands-free devices) }\end{array}$ & 78.3 & 4.1 & 1 \\
\hline Increasing the fines for cellphone infractions & 77.9 & 4.2 & 1 \\
\hline $\begin{array}{l}\text { Technological advances made by car manufacturers that restrict } \\
\text { cellphone capabilities at certain speeds or driving conditions }\end{array}$ & 72.4 & 3.9 & 1.2 \\
\hline $\begin{array}{l}\text { Technological advances made by cellphone manufacturers that restrict } \\
\text { cellphone capabilities at certain speeds or driving conditions }\end{array}$ & 72.3 & 3.9 & 1.2 \\
\hline Increasing the number of points for cellphone infractions & 70 & 4 & 1.1 \\
\hline No single measure will reduce cellphone use among drivers & 64.4 & 3.7 & 1.2 \\
\hline
\end{tabular}

${ }^{\star}$ This question asked which prevention measures could substantially reduce cellphone use among drivers. The prevention measures listed above were posed. Responses were on a 5-point Likert scale ranging from 'Strongly disagree (1)' to 'Strongly agree (5)'. The mean value along with the percentage of respondents who 'Strongly agreed' or 'Agreed' with the statement were combined and shown. The response rate to this question was $82 \%$. 
can only be convinced to change their behaviour through intervention or encouraged to do so through legislation. However, active enforcement is crucial to this equation. Traffic safety studies have shown that drivers will change their behaviour if they perceive that there is an increased risk of being apprehended (ie, risk vs reward). ${ }^{48}$ As this study has shown, numerous barriers to enforcement exist particularly for UTB which is the most common law in effect. Laws with more barriers to enforcement are less likely to be enforced. ${ }^{8}$ This study identified numerous opportunities to strengthen existing or future CPWD laws. These policy changes will not only make traffic safety enforcement easier for police, but may also protect road users from unintentional morbidity and mortality.

Contributors TMR and MZ contributed to the design of the study. TMR obtained the data and performed the analysis. TMR and MZ interpreted the data. All authors had full access to the data in the study and take responsibility for the integrity of the data and the accuracy of the data analysis. All authors contributed to the manuscript preparation and approved the final version.

Funding TMR received support from the Centers of Disease Control and Prevention grant R49CE002109 and from the National Institutes of General Medical Sciences grant 5U54GM104942-04. MZ received support from National Institutes of Health grants R01AG050581 and R01HD074594. The funding agencies had no role in the design of the study, collection, analysis or interpretation of the results, or in the writing of this manuscript.

Competing interests None declared.

Patient consent for publication Not required.

Ethics approval Institutional Review Board approval was obtained for this project from West Virginia University (Protocol \#1906609479).

Provenance and peer review Not commissioned; externally peer reviewed.

Data availability statement № additional data are available.

Supplemental material This content has been supplied by the author(s). It has not been vetted by BMJ Publishing Group Limited (BMJ) and may not have been peer-reviewed. Any opinions or recommendations discussed are solely those of the author(s) and are not endorsed by BMJ. BMJ disclaims all liability and responsibility arising from any reliance placed on the content. Where the content includes any translated material, BMJ does not warrant the accuracy and reliability of the translations (including but not limited to local regulations, clinical guidelines, terminology, drug names and drug dosages), and is not responsible for any error and/or omissions arising from translation and adaptation or otherwise.

Open access This is an open access article distributed in accordance with the Creative Commons Attribution Non Commercial (CC BY-NC 4.0) license, which permits others to distribute, remix, adapt, build upon this work non-commercially, and license their derivative works on different terms, provided the original work is properly cited, appropriate credit is given, any changes made indicated, and the use is non-commercial. See: http://creativecommons.org/licenses/by-nc/4.0/.

ORCID iD

Toni Marie Rudisill http://orcid.org/0000-0002-2019-4274

\section{REFERENCES}

1 Insurance Institute for Highway Safety. Distracted driving, 2020. Available: https://www.iihs.org/topics/distracted-driving\#cellphonelaws

2 Stanojević P, Jovanović D, Lajunen T. Influence of traffic enforcement on the attitudes and behavior of drivers. Accid Anal Prev 2013;52:29-38.

3 Arhin S, Jones P, Anderson MF. Evaluation of safety surrogates of traffic enforcement at Signalized Intersections. J Safety Engineering 2016;5:1-7.

4 Rudisill TM, Zhu M. Who actually receives cell phone use while driving citations and how much are these laws enforced among states? A descriptive, cross-sectional study. BMJ Open 2016;6:e011381.
5 Maher A, Ott P. Effects of New Jersey's cell phone/text ban. Piscataway, NJ: Rutgers University, 2013.

6 McCartt AT, Geary LL. Longer term effects of new York state's law on drivers' handheld cell phone use. Inj Prev 2004;10:11-15.

7 McCartt AT, Hellinga LA. Longer-Term effects of Washington, DC, law on drivers' hand-held cell phone use. Traffic Inj Prev 2007;8:199-204.

8 Lacey JH, Jones RK, Wiliszowski $\mathrm{CH}$. Zero tolerance laws for youth: four states' experience (report No. HS 809 053. Washington, DC: United States Department of Transportation, 2000.

9 Rudisill TM, Baus AD, Jarrett T. Challenges of enforcing cell phone use while driving laws among police: a qualitative study. Inj Prev 2019;25:494-500.

10 Nevin PE, Blanar L, Kirk AP, et al. "I wasn't texting; I was just reading an email ...": a qualitative study of distracted driving enforcement in Washington State. Inj Prev 2017;23:165-70.

11 Rudisill TM. The development and reliability of a national survey of police officers regarding the enforceability of cell phone use while driving laws. Transp Res Interdiscip Perspect 2020;6:100140.

12 Austin PC, Merlo J. Intermediate and advanced topics in multilevel logistic regression analysis. Stat Med 2017;36:3257-77.

13 AAA Foundation for Traffic Safety. 2018 traffic safety culture index, 2019. Available: https://aaafoundation.org/wp-content/uploads/2019/ 06/2018-TSCI-FINAL-061819_updated.pdf

14 Hill L, Rybar J, Jahns J, et al. 'Just drive': an Employee-Based intervention to reduce Distracted driving. J Community Health 2020;45:370-6.

15 Frietze G, Cohn LD. Texting and tombstones: impact of mortality salience on risky driving intentions. Transp Res Part F Traffic Psychol Behav 2018;59:1-11.

16 McDonald CC, Brawner BM, Fargo J, et al. Development of a theoretically Grounded, web-based intervention to reduce adolescent driver inattention. J Sch Nurs 2018;34:270-80.

17 Fournier AK, Berry TD, Frisch S. It can W8: a community intervention to decrease distracted driving. J Prev Interv Community 2016;44:186-98.

18 McDonald CC, Fargo JD, Swope J, et al. Initial testing of a webbased intervention to reduce adolescent driver inattention: a randomized controlled trial. J Emerg Nurs 2021;47:88-100.

19 Gras M-E, Font-Mayolas S, Planes M, et al. The impact of the penalty point system on the behaviour of young drivers and passengers in Spain. Saf Sci 2014;70:270-5.

20 Lawpoolsri S, Li J, Braver ER. Do speeding tickets reduce the likelihood of receiving subsequent speeding tickets? A longitudinal study of speeding violators in Maryland. Traffic Inj Prev 2007;8:26-34.

21 McCartt AT, Leaf WA, Farmer CM. Effects of Washington state's alcohol ignition interlock laws on DUI recidivism: an update. Traffic Inj Prev 2018;19:665-74.

22 McCartt AT, Leaf WA, Farmer CM, et al. Washington state's alcohol ignition interlock law: effects on recidivism among first-time DUI offenders. Traffic Inj Prev 2013;14:215-29.

23 Montoro González L, Roca Ruiz J, Tortosa Gil F. [Influence of the penalty point system on driving behaviour: drivers' point of view]. Psicothema 2008;20:652-8.

24 Sze NN, Wong SC, Pei X, et al. Is a combined enforcement and penalty strategy effective in combating red light violations? an aggregate model of violation behavior in Hong Kong. Accid Anal Prev 2011;43:265-71.

25 Rudisill TM, Zhu M. The association between states' Texting regulations and the prevalence of texting while driving among U.S. high school students. Ann Epidemiol 2015;25:888-93.

26 Atchley P, Hadlock C, Lane S. Stuck in the 70S: the role of social norms in distracted driving. Accid Anal Prev 2012;48:279-84.

27 Rimal RN, Real K. How Behaviors are influenced by perceived norms: a test of the theory of normative social behavior. Communication Research 2005;32:389-414.

28 Kallgren CA, Reno RR, Cialdini RB. A focus theory of normative conduct: when norms do and do not affect behavior. Personality and Social Psychology Bulletin 2000;26:1002-12.

29 Oviedo-Trespalacios O, King M, Vaezipour A, et al. Can our phones keep us safe? A content analysis of smartphone applications to prevent mobile phone distracted driving. Transp Res Part F Traffic Psychol Behav 2019;60:657-68.

30 Coben JH, Zhu M. Keeping an eye on distracted driving. JAMA 2013;309:877-8.

31 Delgado MK, McDonald CC, Winston FK, et al. Attitudes on technological, social, and behavioral economic strategies to reduce cellphone use among teens while driving. Traffic Inj Prev 2018;19:569-76.

32 Oviedo-Trespalacios O, Williamson A, King M. User preferences and design recommendations for voluntary smartphone applications to 
prevent distracted driving. Transp Res Part F Traffic Psychol Behav 2019;64:47-57.

33 Funkhouser D, Sayer J. Cellphone filter/blocker techonology field test (report No. HS 811 863). Washington, DC: United States Department of Transportation, 2013.

34 McDonald CC, Ward K, Huang Y, et al. Novel smartphone-based measures of cell phone use while driving in a sample of newly licensed adolescent drivers. Health Educ Behav 2019;46:10-14

35 Creaser JI, Edwards CJ, Morris NL, et al. Are cellular phone blocking applications effective for novice teen drivers? J Safety Res 2015;54:75.e29-8.

36 Morain SR, Gielen AC, Bhalla K. Automated speed enforcement systems to reduce traffic-related injuries: closing the policy implementation gap. Inj Prev 2016;22:79-83.

37 Fell J. Underutilized strategies in traffic safety: results of a nationally representative survey. Traffic Inj Prev 2019;20:S57-62.

38 Debinski B, Clegg Smith K, Gielen A. Public opinion on motor vehicle-related injury prevention policies: a systematic review of a decade of research. Traffic Inj Prev 2014;15:243-51.

39 Jones DJ. Patrolling traffic by camera: an analysis of Photo-Enforced traffic citations and the common law requirement that a Warrantless Misdemeanor arrest take place immediately. Revista de Derecho Puertorriqueño 2006;45:197-211.

40 Wissinger LM, Hummer JE, Milazzo JS. Using focus groups to investigate issues of red light running. Transp Res Rec 2000;1734:38-45.
41 Smith DM, McFadden J, Passetti KA. Automated enforcement of red light running technology and programs: a review. Transp Res Rec 2000;1734:29-37.

42 Retting RA, Ferguson SA, Farmer CM. Reducing red light running through longer yellow signal timing and red light camera enforcement: results of a field investigation. Accid Anal Prev 2008;40:327-33.

43 Retting RA, Farmer CM, McCartt AT. Evaluation of automated speed enforcement in Montgomery County, Maryland. Traffic Inj Prev 2008;9:440-5.

44 Quistberg DA, Thompson LL, Curtin J, et al. Impact of automated photo enforcement of vehicle speed in school zones: interrupted time series analysis. Inj Prev 2019;25:400-6.

45 Porter BE, Johnson KL, Bland JF. Turning off the cameras: red light running characteristics and rates after photo enforcement legislation expired. Accid Anal Prev 2013;50:1104-11.

46 Cunningham CM, Hummer JE. Evaluating the effectiveness of RedLight running camera enforcement in Raleigh, North Carolina. Journal of Transportation Safety \& Security 2010;2:312-24.

47 Nix J, Pickett JT, Baek H, et al. Police research, officer surveys, and response rates. Policing and Society 2019;29:530-50.

48 Cazzulino F, Burke RV, Muller V, et al. Cell phones and young drivers: a systematic review regarding the association between psychological factors and prevention. Traffic Inj Prev 2014;15:234-42.

49 Yao J, Johnson MB, Beck KH. Predicting DUI decisions in different legal environments: investigating deterrence with a conjoint experiment. Traffic Inj Prev 2014;15:213-21. 